German society. (For a comparative look at generational change in the two Germanys see Gebhard L. Schweigler, Nationalbezonsstsein in der BRD und der $D D R$, Dusseldorf, 1973.)

John STARRELS

The George Washington University

\title{
AGRARNYI KRIZIS I RASPAD AGRARNOGO BLOKA STRAN VOS- TOCHNOI I IUGO-VOSTOCHNOI EVROPY (1930-1933 GODY). Вy M. M. Goranovich. Moscow: "Nauka," 1971. 222 pp. 1.37 rubles.
}

During the Great Depression those countries in Eastern Europe for which agricultural exports were important made several attempts to save themselves by joining forces. In this book a Soviet scholar tries to provide a detailed study of those efforts. The author is eminently qualified for this task, having already published an interesting study of the Green International in Prague. The scope of the book is somewhat narrower than the title would suggest, since the author makes it clear at the outset that he will not devote much attention either to the nature of the agrarian crisis or to the internal agrarian policies of the reigning political movements in Eastern Europe.

The book is a brief and convenient account of the effect of the Depression on East European trade, and of the unsuccessful attempts by East European states to organize a united front against the outside world in order to obtain preferential treatment for their agricultural goods in Western Europe. When Goranovich turns, however, from description to explanation, the results are somewhat less satisfying. $\mathrm{He}$ is content with Marxist clichés about the greed of capitalist powers and the inherent instability of capitalist economic systems. In any case, it would be impossible to explain the behavior of leading politicians in Eastern Europe without sorting out their personalities and their party ideologies, and the distinctive internal problems of each country. The author provides something unusual in Soviet monographs, a critical bibliographical essay at the end. Although he does refer to many of the most useful Western documentary sources, he does not include any relevant English-language studies, such as those by Vondracek and Svennilson, but instead recommends most highly the rather superficial works published by the International Agrarian Institute in Moscow in the thirties.

GEORGE D. JACKSON Hofstra University

HUNGARY. By Paul Ignotus. Nations of the Modern World Series. New York and Washington: Praeger Publishers, 1972. 333 pp. $\$ 11.50$.

Although not an historical survey in the traditional sense, Ignotus's Hungary is a work that should be read by everyone interested in Hungarian history and culture. The two main reasons are the author himself and his tendency to treat topics usually left untouched by standard one-volume syntheses.

The son of one of the great literati of Hungary of the late dualist age (ca. 1900-1918), and an important left-wing liberal intellectual himself, Ignotus has produced in this book a work that is perhaps too selective and impressionistic, yet at the same time is enlightening and refreshing. Thus his coverage of Hungarian history-particularly the pre-nineteenth-century period-is arbitrary, and his 